OPEN ACCESS

Edited by:

Rob Bailis,

Stockholm Environment Institute,

Sweden

Reviewed by:

Milton Kanashiro,

Embrapa Amazônia Oriental, Brazil

llias Travlos,

Agricultural University of Athens,

Greece

*Correspondence:

M. J. Santos

m.j.ferreiradossantos@uu.nl

Specialty section:

This article was submitted to Agroecology and Land Use Systems,

a section of the journal

Frontiers in Environmental Science

Received: 14 March 2017 Accepted: 29 May 2017

Published: 14 June 2017

Citation:

Santos MJ, Dekker SC, Daioglou V, Braakhekke $M C$ and van Vuuren DP (2017) Modeling the Effects of Future Growing Demand for Charcoal in the

Tropics. Front. Environ. Sci. 5:28.

doi: 10.3389/fenvs.2017.00028

\section{Modeling the Effects of Future Growing Demand for Charcoal in the Tropics}

\author{
M. J. Santos ${ }^{1 *}$, Stefan C. Dekker ${ }^{1}$, Vassilis Daioglou ${ }^{1,2}$, Maarten C. Braakhekke ${ }^{1,2}$ and \\ Detlef $P$. van Vuuren ${ }^{1,2}$
}

${ }^{1}$ Department of Innovation, Environmental and Energy Sciences, Copernicus Institute of Sustainable Development, Utrecht University, Utrecht, Netherlands, ${ }^{2}$ PBL Netherlands Environmental Assessment Agency, The Hague, Netherlands

Global demand for charcoal is increasing mainly due to urban population in developing countries. More than half the global population now lives in cities, and urban-dwellers are restricted to charcoal use because of easiness of production, access, transport, and tradition. Increasing demand for charcoal, however, may lead to increasing impacts on forests, food, and water resources, and may even create additional pressures on the climate system. Here we assess how different charcoal scenarios based on the Shared Socio-economic Pathways (SSP) relate to potential biomass supply. For this, we use the energy model TIMER to project the demand for fuelwood and charcoal for different socio-economic pathways for urban and rural populations, globally, and for four tropical regions (Central America, South America, Africa and Indonesia). Second, we assess whether the biomass demands for each scenario can be met with current and projected forest biomass estimated with remote sensing and modeled Net Primary Productivity (NPP) using a Dynamic Global Vegetation Model (LPJ-GUESS). Currently one third of residential energy use is based on traditional bioenergy, including charcoal. Globally, biomass needs by urban households by 2100 under the most sustainable scenario, SSP1, are of $14.4 \mathrm{mi}$ ton biomass for charcoal plus $17.1 \mathrm{mi}$ ton biomass for fuelwood (31.5 mi ton biomass in total). Under SSP3, the least sustainable scenario, we project a need of $205 \mathrm{mi}$ tons biomass for charcoal plus $243.8 \mathrm{mi}$ ton biomass for fuelwood by 2100 (total of $450 \mathrm{mi}$ ton biomass). Africa and South America contribute the most for this biomass demand, however, all areas are able to meet the demand. We find that the future of the charcoal sector is not dire. Charcoal represents a small fraction of the energy requirements, but its biomass demands are disproportionate and in some regions require a large fraction of forest. This could be because of large growing populations moving to urban areas, conversion rates, production inefficiencies, and regions that despite available alternative energy sources still use a substantial amount of charcoal. We present a framework that combines Integrated Assessment Models and local conditions to assess whether a sustainable sector can be achieved.

Keywords: traditional bioenergy, charcoal, integrated assessment, supply and demand, biomass, dynamic vegetation model, remote sensing 


\section{INTRODUCTION}

More than half of the global population now lives in cities, leading to important consequences for energy consumption (Grubler et al., 2012). Urbanization will influence the type of fuels used and also the total energy consumption for different functions, and choice depends on income (Poumanyvong and Kaneko, 2010). Charcoal is the main cooking fuel especially in urban areas in sub-Saharan Africa, South Asia, Latin America and the Caribbean (Ghilardi et al., 2013; Mwampamba et al., 2013; Zulu and Richardson, 2013). Globally, charcoal corresponds to a small fraction of the total energy mix (Bond et al., 2004). However, with continued urbanization charcoal will remain an important fuel locally (Arnold et al., 2006; Ghilardi et al., 2013) and will likely become an important fuel globally, as Africa and South America are major producers and exporters (Hillring, 2006).

The reason for the preference for charcoal by part of the urban dwellers in developing countries is that it has higher energy content than firewood $(32-33 \mathrm{MJ} / \mathrm{kg}$ in charcoal vs. 18-19 MJ/kg in fuelwood; Wood and Baldwin, 1985), has a more accessible and reliable supply, is easier to transport, is inexpensive, stores more easily, and burns more cleanly, i.e., with less smoke (Zulu and Richardson, 2013). Worldwide, about 1.5 to 2 million deaths per year are caused by indoor air pollution from burning biomass, with the majority of the contribution coming from unprocessed wood rather than charcoal (Torres-Duque et al., 2008). However, depending on the charcoal production method, 3 to $12 \mathrm{~kg}$ of biomass are required to produce $1 \mathrm{~kg}$ of charcoal. Further, charcoal's non$\mathrm{CO}_{2}$ greenhouse gas emissions are 6-13 times higher than traditional woodfuels, which includes the contribution of the emissions during charcoal production phase (Torres-Duque et al., 2008). Charcoal production has many environmental impacts, namely deforestation and forest degradation, followed by erosion impacting the catchment hydrology, and emissions of greenhouse gases. Charcoal production is responsible for 7\% tropical forest loss (Chidumayo and Gumbo, 2013), making it important to assess whether there is enough forest to sustain this production at local and global scales, particularly if demand is to increase with further urbanization. Further, charcoal production could affect the microclimate, leading to more extreme temperatures, wind and water erosion even when the kiln-site is no longer in use as regeneration of the ecosystems requires a number of years (Gómez-Luna et al., 2009). Finally, charcoal production may compete with the production of food, reduce water resources, and other services forests provide (Fisher et al., 2011; Chidumayo and Gumbo, 2013). Besides these negative effects, charcoal may also be beneficial as its application to soils contributes to higher organic matter content and soil fertility (Glaser et al., 2002). If managed properly, some researchers have indicated that charcoal could be a renewable energy source with a theoretical net carbon emission close to zero (Piketty, 2015) even becoming a sustainable sector given that good governance is put in place (Neufeldt et al., 2015).

Due to the expected continuation of urbanization trends, demand for charcoal could increase in the coming decades (Mwampamba et al., 2013; Zulu and Richardson, 2013), depending on the competition with other fuels. As such, increasing demand for charcoal may create additional pressures on the climate system (Bailis et al., 2015) challenging policy goals for energy transitions (Zulu and Richardson, 2013), food security (Mwampamba et al., 2013), and biodiversity (Chidumayo and Gumbo, 2013). Alternatively, energy transition from charcoal to renewable fuels such as pellets, bio-ethanol, renewable electricity, etc. needs to account for land use emissions which could arise from maintaining forest areas (Peters et al., 2013). It is therefore important to have a more detailed assessment of the implications of using charcoal as a bioenergy source, i.e., the dynamics of demand and supply of charcoal and its impacts. The nexus approach for charcoal aims to take an integrated consideration of the environmental, societal and economic issues related to charcoal supply and demand. It also aims at understanding how the effects of demand and supply in one sector percolate across other sectors. One way to operationalize the nexus approach is through the use of Integrated Assessment Models (IAM).

Here, we use IAM to project future global and regional demands for energy and estimate the share of charcoal in such projections. We use the energy model TIMER (a part of the IAM IMAGE) to project the demand for secondary energy from fuelwood and charcoal, and the primary biomass "equivalents." We do that by estimating biomass "equivalents" that correspond to a 1:5 conversion for charcoal and 1:1 conversion for other biomass sources. We then compare the demand with the current and over time forest biomass, and use this information to discuss the nexus between charcoal and its coupled sectors, globally and for four tropical regions with high charcoal demand (Central America, South America, Africa and Indonesia).

\section{METHODS}

\section{Study System}

World charcoal production approached 50 million tones in 2010 (FAO, 2016). Recent estimates suggest that $51 \%$ of charcoal production comes from Africa and 35\% from South America, but not all the charcoal stays where it is produced and major exports of charcoal occur in Indonesia, Malaysia and China, while major imports occur in Europe, Korea and Japan (Hillring, 2006; http://www.trademap.org). Most of this production is to meet demands for charcoal for cooking and heating. Charcoal production is arguably one of the most ancient human engineering processes, dating from 38,000 year ago. Charcoal is produced by slow pyrolysis, i.e., heating of wood in the absence of oxygen (Antal and Gronli, 2003). This is achieved in its most traditional production way, by stacking wood in a pile, sealing it with a layer of grass and soil, and igniting the wood at the kiln entrance, i.e., the structure produced by the wood stack and soil layer (Figure 1).

We used the Integrated Assessment Model IMAGE (Stehfest et al., 2014) to project the demand for residential energy for a number of energy carriers (solids, liquids, gaseous, modern bioenergy, traditional fuels including charcoal, hydrogen, secondary heat, and electricity). To determine the fraction of charcoal in traditional fuels, we assume the proportions of different traditional fuels in Bond et al. (2004) and Fernandes 
A

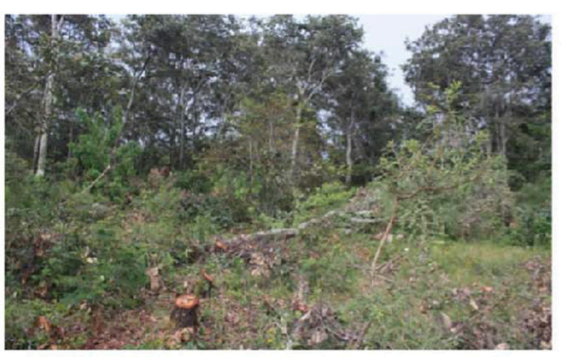

C

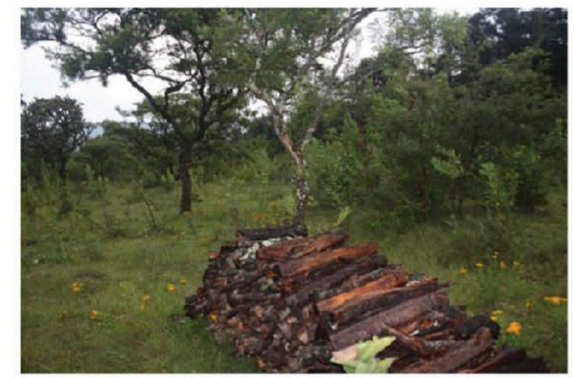

E

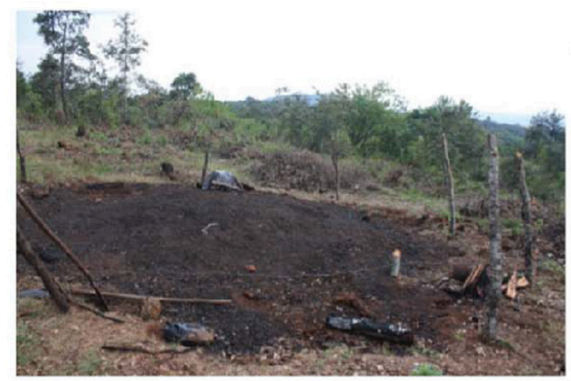

B

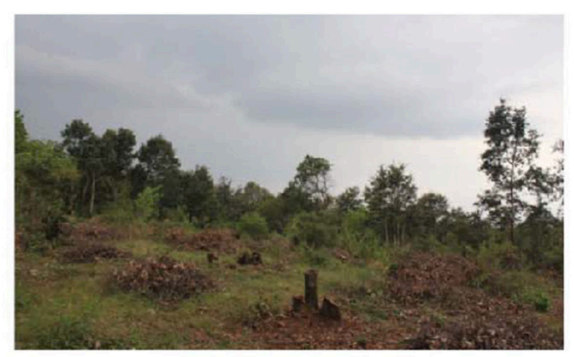

D

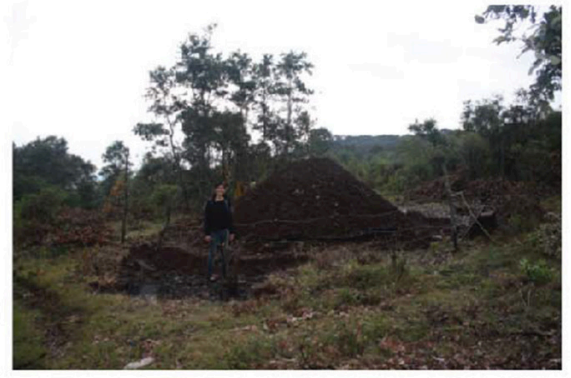

F

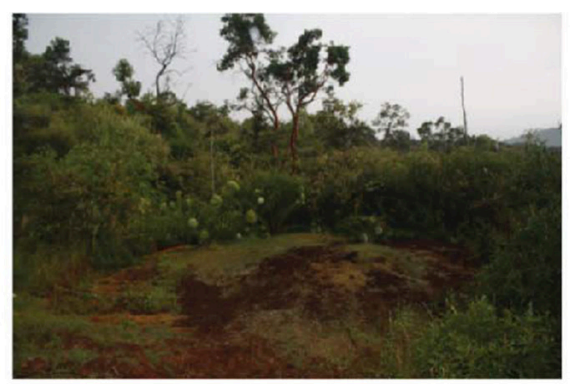

FIGURE 1 | Charcoal production system in Mexico: (A) deforestation for biomass, (B) post deforestation, (C) biomass for charcoal, (D) kiln, (E) kiln site post-production, and (F) kiln site 5 years post-production.

et al. (2007), which varies between 2 and 30\%. We then determine biomass needed to meet charcoal and fuelwood demand by estimating "biomass equivalents," with a 1:5 conversion for charcoal and 1:1 conversion for fuelwood (http://www.fao.org/docrep/x5328e/x5328e02.htm).

This demand is determined for three different potential futures as projected in the Shared Socio-economic Pathway scenarios (Riahi et al., 2017; van Vuuren et al., 2017). Second, we compare projected demands with existing above ground biomass estimated using remote sensing (Saatchi et al., 2011; Baccini et al., 2012). Further, with modeled estimates of Net Primary Productivity (NPP) from the Dynamic Global Vegetation Model - LPJ-GUESS we have an estimate if the forest provides enough increase in biomass to fulfill the charcoal demands while other services remain. We do this globally and again for four tropical regions (Central America, South America, Africa, and Indonesia) to assess whether there are differences at global and local scales, and whether there are differences for urban and rural populations.

\section{Projections of Future Energy Demand}

The Integrated Model to Assess the Global Environment (IMAGE) has been developed in order investigate the interactions between human and natural systems with the aim of assessing global change. A detailed description of the model can be found in Stehfest et al. (2014). Among other things, IMAGE provides long term (2100) global projections of energy supply and demand, land use and land use change, and consequent effects on the climate system.

In this analysis we primarily use projections of energy demand for the residential sector as represented in IMAGE (Daioglou et al., 2012). Residential energy demand is determined for different end-use functions (cooking, water heating, space heating, lighting and appliances), and different potential energy carriers (traditional fuels, coal, oil, gas, electricity, etc.) that compete with each other based on their relative costs. The model is particularly appropriate as it explicitly takes into account differences in urban and rural energy use, as well as five income quintiles within each of these groups. Furthermore, it explicitly takes into account the access of poor households to modern energy carriers through endogenously modeled electrification rates, consumer discount rates and other price effects. Following, the model was used in order to determine possible future demand levels of traditional fuels and charcoal.

The demand for traditional fuels depends on the household income, and the prices of different energy carriers. Traditional 
fuels are assumed to have no monetary cost and are thus used by households which cannot afford modern energy carriers either because they are too expensive, or the do not have access to them (i.e., they are not electrified). The model is calibrated in order to reproduce International Energy Agency data (19712010; https://www.iea.org/) which provides historic traditional fuel use, as well as modern energy carriers. The demand of traditional fuels is disaggregated among fuelwood, crop residues, dung and charcoal, with the volume of each calibrated to historic data and it is assumed that historic and future charcoal use is limited to urban households (Fernandes et al., 2007). Though the model includes the trade of modern energy carriers, this is not the case for traditional fuels, including charcoal.

\section{Scenario Projections: Shared Socio-Economic Pathways}

The IMAGE model has recently been used in order to assess energy and land use pathways for various baseline and climate mitigation pathways based on the Shared Socioeconomic Pathways (Kriegler et al., 2012; Riahi et al., 2017; van Vuuren et al., 2017). The SSPs define distinctly different pathways about future socio-economic developments and are designed to span a wide range of combinations of challenges to mitigation and adaptation to climate change. For this study we use IMAGE results for charcoal demand for the SSP1, SSP2, and SSP3 baselines (van Vuuren et al., 2017). SSP1, also named as Sustainability, represents a world with low challenges for climate adaptation and mitigation, with educational and health investments accelerating the demographic transitions, increases in economic welfare and low resource and energy intensity. SSP2, named Middle of the Road, represents a world with medium challenges to both mitigation and adaptation, environmental systems continuing to experience degradation, and some improvements and overall the intensity of resource and energy use declines. Global population growth plateaus in the second half of the century and economic inequality improves only slowly. Finally, SSP3, named Regional Rivalry represents a world with large challenges to both adaptation and mitigation, with slow economic development, worsening inequality, high population growth and a low priority for addressing environmental concerns. In the context of this study, the SSPs provide divergent storylines for urbanization, economic development, inequality among urban and rural households, and actions toward access and use of improved energy sources. For instance, the lower economic growth, higher economic inequality and population growth in SSP3 tend to increase the demand for lower quality fuels while the opposite effects are observed in SSP1.

\section{Global and Regional Demands for Energy and Biomass under SSPs}

We produced outputs at the global scale but also for the four selected regions, Central America, South America, Africa and Indonesia. We focus on these four regions because charcoal is still very important as either the main source of energy (Africa), co-use charcoal along other fuels (Indonesia), continue to use charcoal for cultural reasons despite the dominant use of other fuel sources (Central America), or provide charcoal to other regions of the world (South America; Hillring, 2006; Ghilardi et al., 2013; Mwampamba et al., 2013). We projected global and regional demands for the required biomass across the three SSP scenarios. The demand is measured in biomass, which for comparative purposes is converted by a factor of $1 / 2$ to Carbon.

\section{Supply of Biomass: Current Biomass}

We used the outputs from the GEOCARBON global aboveground biomass at $1 \mathrm{~km}$ resolution to estimate the supply of biomass to each of the four regions of the study (https://www.bgc-jena.mpg.de/geodb/projects/Home.php;

Saatchi et al., 2011; Baccini et al., 2012). We used this data because it is one of the most recent and finer scale global datasets where biomass is consistently estimated across regions. Given the coarse scale of our analysis we believe that this data product provides sufficient resolution and an accurate figure of standing biomass. There is a more recent pan-tropical map of above ground biomass (Avitabile et al., 2016), that is incorporated into the GEOCARBON map. We chose not to use directly the product of Avitabile et al. (2016) because it does not include Central America and Africa in its full extent. The map combines the biomass estimates of Avitabile et al. (2016) and Santoro et al. (2015) in ton C.ha ${ }^{-1}$. The map only covers forest areas, i.e., areas with a dominance of tree cover as in the Global Land Cover map of 2000 (Bartholomé and Belward, 2005). On top of these biomass measurements, we excluded IUCN protected areas which cover about $15 \%$ of the global terrestrial surface. The spatial extent of global protected areas in 2016 was obtained from World Database on Protected Areas (https://www.iucn.org/ theme/protected-areas/our-work/world-database-protectedareas). The biomass values were converted to $\mathrm{kg} \mathrm{C} . \mathrm{m}^{-2}$ to compare with the modeled Net Primary Productivity (see below).

\section{Net above Ground Biomass Accumulation}

To calculate the net increase of biomass, we used the LPJ-GUESS model (Lund-Potsdam-Jena General Ecosystem Simulator; Smith et al., 2001), which simulates global vegetation dynamics and biogeochemical cycling for terrestrial ecosystems. The model uses 11 plant functional types (PFTs) to represent the most important vegetation types for temperate, tropical, boreal and grassland biomes. Our simulations focus on natural vegetation only, i.e., all croplands and pastures are not included. Each PFT and biome has its own specific parameterization for plant physiological and biogeochemical processes of carbon and nitrogen (Smith et al., 2001). The occurrence of the PFTs is predicted based on bioclimatic limits and competition for light and soil resources. For tree PFTs the model uses an individual based approach, representing multiple age cohorts that can co-occur in a single stand. Several processes, including mortality and establishment of trees, as well as disturbances are modeled stochastically. Grid cell mean dynamics are based on simulation for 20 replicate subgrid units ("patches"). The model was run on a global grid of $0.5^{\circ} \times 0.5^{\circ}$ degrees (approximately $50 \times 50 \mathrm{~km}$ at the equator) based on climate data from the CRU TS 3.0 data set (Mitchell and Jones, 2005). To initialize the model, we used a spin-up of 500 
years to bring vegetation and soil carbon pools approximately at equilibrium, during which a repeated cycle of climate forcing was used, based on the first 10 years of the input dataset.

For our analysis, we were interested in the annual increase of wood in forests. From the simulated average annual carbon fluxes, we used Net Primary Productivity (NPP $\left[\mathrm{kgC} \cdot \mathrm{m}^{-2} \cdot\right.$ year $\left.\left.^{-1}\right]\right)$, which is the net effect of Gross Primary Productivity minus respiration losses. NPP reflects above and below ground biomass, both for all or for selected PFTs. We report total NPP, as well as the values of above ground biomass for NPP total and for the tree PFT (NPP tree). NPP is the sum of $\mathrm{NPP}_{\text {wood }}, \mathrm{NPP}_{\text {canopy, }}$ and $\mathrm{NPP}_{\text {fine roots; }}$ Malhi et al. (2011) estimated an average of $30 \%$ biomass allocated to $\mathrm{NPP}_{\text {wood, }}$, although the allocation of wood to fine roots is highly variable. Thus we report on NPP by a factor of 0.3 as a representation of the aboveground fraction of NPP. To calculate total available annual $\mathrm{NPP}_{\text {wood }}$ and $\mathrm{NPP}_{\text {tree }}$ from forests under future projections, we estimated the change in forest area. We used the global forest projections under the different SSP scenarios for the time slices 2010, 2015, 2030, 2050, and 2100 (van Vuuren et al., 2017) also on $0.5 \times 0.5$ degree resolution. The extent of land use change and deforestation are taken into account as the different scenarios predict different population growths and therefore different demands for food production and land use.

\section{RESULTS}

\section{Projected Energy Demand for Residential Uses}

Currently, about one third of residential energy use is based on traditional bioenergy, including charcoal (see Figures 2D-F, about 30 EJ from the 90 EJ for traditional bioenergy in 2015). The share of traditional bioenergy in the residential sector reduces rapidly in SSP1 (about 55\% of the 2015 values of traditional biofuels by $2020,18 \%$ by $2030,7 \%$ by 2050 , and $2.5 \%$ by 2100 ; Figure 2A), as urban populations become wealthier and policies are introduced to provide access to modern energy consistent with the Energy for All objectives (Table S1). In contrast, SSP3 projects a traditional energy demand relatively constant (between 78 and $100 \%$ of the 2015 values, Figure 2C), given the relatively high population projections. The SSP2 projections are in between these two extremes. Most of the projected energy demand from all SSPs is to be used for cooking and only a minor fraction is dedicated to space and water heating (Figure 2B).

\section{Biomass Needed to Meet Projected Energy Needs}

Globally, under the most sustainable scenario, SSP1, and because it is assumed that as urban populations become wealthier they replace charcoal use by other fuelwood, $14.4 \mathrm{mi}$ ton biomass will be needed for charcoal plus $17.1 \mathrm{mi}$ ton biomass for fuelwood by 2100 . In the worst case scenario, SSP3, we project a greater than 10-fold demand compared to SSP1. By 2100, $205 \mathrm{mi}$ tons of biomass for charcoal plus $244 \mathrm{mi}$ ton of biomass for fuelwood will be needed (Figure 3).
Currently, two regions contribute the most to the global biomass demand, 1/3 Africa and 1/4 South America (Figures 3C,D). In the most sustainable scenario (SSP1), African urban populations are projected to require $5.5 \mathrm{mi}$ ton biomass for charcoal plus $1.7 \mathrm{mi}$ ton for fuelwood. In the SSP1 scenario, South America is projected to require $1.7 \mathrm{mi}$ ton biomass for charcoal plus $0.6 \mathrm{mi}$ ton biomass for fuelwood. In the least sustainable scenario, a total of $189.1 \mathrm{mi}$ ton of biomass would be required for African urban populations (145.3 mi ton of biomass for charcoal, $43.8 \mathrm{mi}$ ton of biomass for fuelwood in urban areas) and a total of $60.6 \mathrm{mi}$ ton of biomass for South America (45.1 $\mathrm{mi}$ ton $\mathrm{mi}$ ton of biomass for charcoal plus $15.5 \mathrm{mi}$ ton $\mathrm{mi}$ ton of biomass for fuelwood). This is because urbanization and population growth are projected to be the highest for Africa (see Table S1), and South America supplies charcoal elsewhere. Indonesia and Central America have the lowest demands (SSP1: a total of $1.3 \mathrm{mi}$ ton biomass for Central America and $3.1 \mathrm{mi}$ ton biomass for Indonesia; SSP3: $31.2 \mathrm{mi}$ ton biomass for Central America, $12.6 \mathrm{mi}$ ton biomass for Indonesia; Figures 3B,C). In general, the demand for biomass decreases over time, except for SSP3, and in Africa and Central America. Indonesia shows the relative sharpest decrease in biomass demand, becoming very close to the needs from Central America (Figure 3).

\section{Current Forest Aboveground Biomass and Net Primary Productivity}

Global estimates of forest aboveground biomass in 2015 were of 43,855.9 mi ton C, of which 25\% (11,259.5 mi ton C biomass) was in protected areas (Table 1). In 2015, each of the regions we analyzed had aboveground biomass values that varied from $404.4 \mathrm{mi}$ ton C in Central America to $13,653 \mathrm{mi}$ ton C in South America. Demands for biomass for charcoal by 2015 converted to mi ton $\mathrm{C}$ show that demand values are relatively small. Most of this demand is from Central America (3\% aboveground biomass needed not in protected areas per year) but in all the other regions biomass equivalents for charcoal are around $0.5 \%$ per year. The results for 2015 are problematic as these rates already suggest a non-sustainable production system, and it is important to acknowledge that estimated needs for biomass are modeled rather than empirical due to the absence of systematic data collected at the global scale.

We next looked into whether forest growth rates (via NPP) could withstand future demands for biomass "equivalents" (for charcoal and fuelwood). Globally, total NPP is 728.24 mi ton C.year ${ }^{-1}$, and is much higher for South America and Africa, while it is almost one order of magnitude lower for Central America and Indonesia (Table 2). However, NPP available for charcoal production (wood or tree PFT) show values about $1 / 3$ smaller than total NPP globally. A comparison of the remote sensing estimates for forest above ground biomass and modeled total NPP are shown in Table S2.

\section{Future NPP under Land Use Change}

Depending on the SSP scenario, forests are replaced by other land uses at different rates (Figure S1) and the resulting future NPP is mapped in Figure 4 for 6 different time slices. Figures 


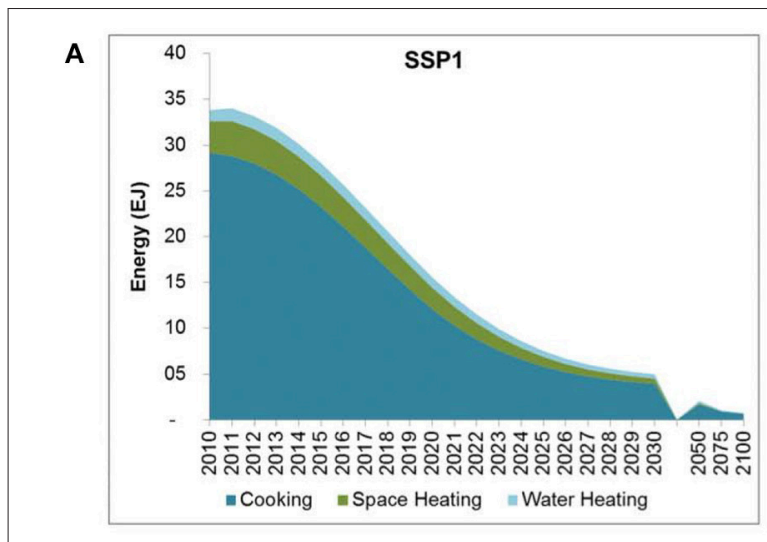

D

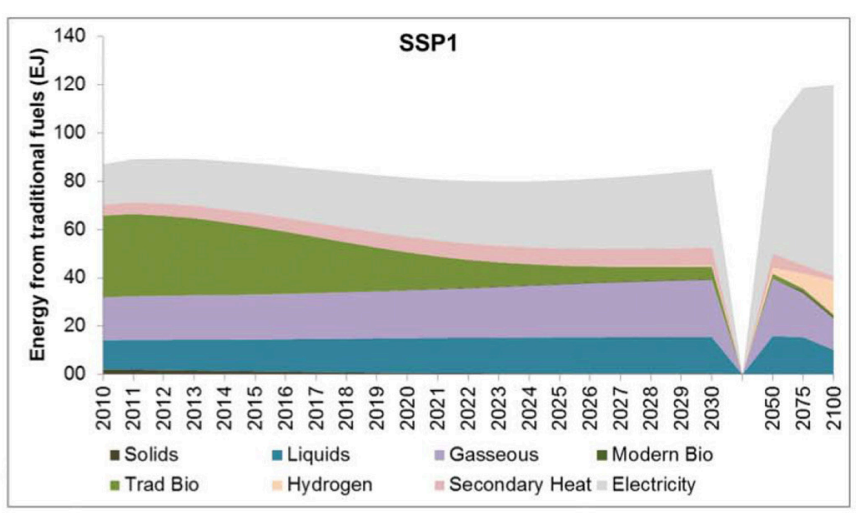

E

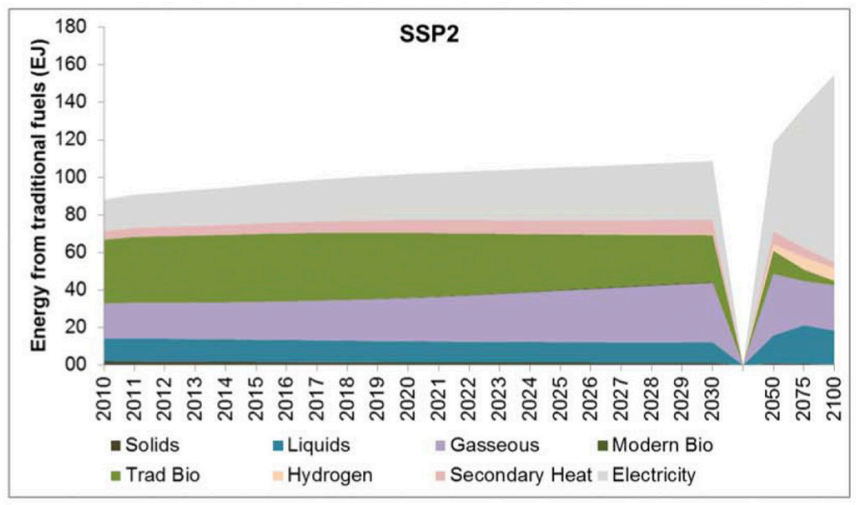

$\mathbf{F}$

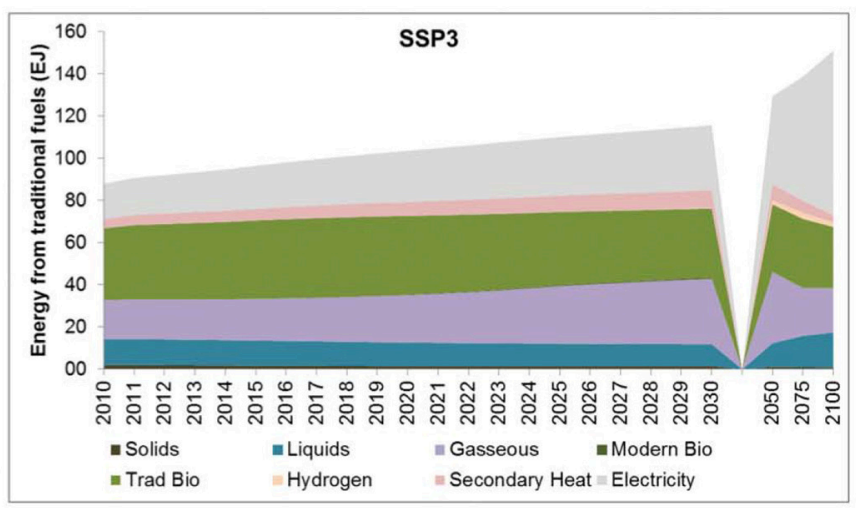

FIGURE 2 | Projections of residential energy demand and the use of traditional energy: (A-C) end-uses supplied by traditional bioenergy, and (D-F) share by energy carrier in total residential energy use (green is traditional bioenergy).

S2-S5 in the Supplementary material shows the detailed NPP per region for the projected futures. SSP3 projects higher land use change, in which even large parts of the Congo Basin are changed. Under this scenario, the Central Amazon Basin remains as forest, as this area is mostly protected (Figure 4 ). The detailed maps for each region, also follow the same pattern, with greater land use change in SSP3 and therefore 2/3 forest loss for Central America (Figure S2), 1/5 for South America (Figure S3), 1/2 loss in Africa (Figure S4), and 1/6 loss in Indonesia (Figure S5). 45\% of forest aboveground biomass is protected in South America, while $34 \%$ for Central America, $21 \%$ in Indonesia, and $17.5 \%$ in Africa.

\section{Demand and Supply Projections}

With increasing demand, forest land uses decrease resulting in a lower supply of NPP. In Figure 5 we plotted the trends of global demand and supply from 2020 to 2100 for the three SSP scenarios. Globally the supply by NPP is always higher than the demand, suggesting that charcoal production is potentially not a large stressor on the system. However, this means that the NPP the forest provides must be harvested in a sustainable way, that ecosystem functioning is not hindered. At a global scale even with the worst case scenario (SSP3) there is two times higher supply than demand (Figure 5A; Table S3). The four regions follow the same global trend, with supply being at least a factor 10 greater 


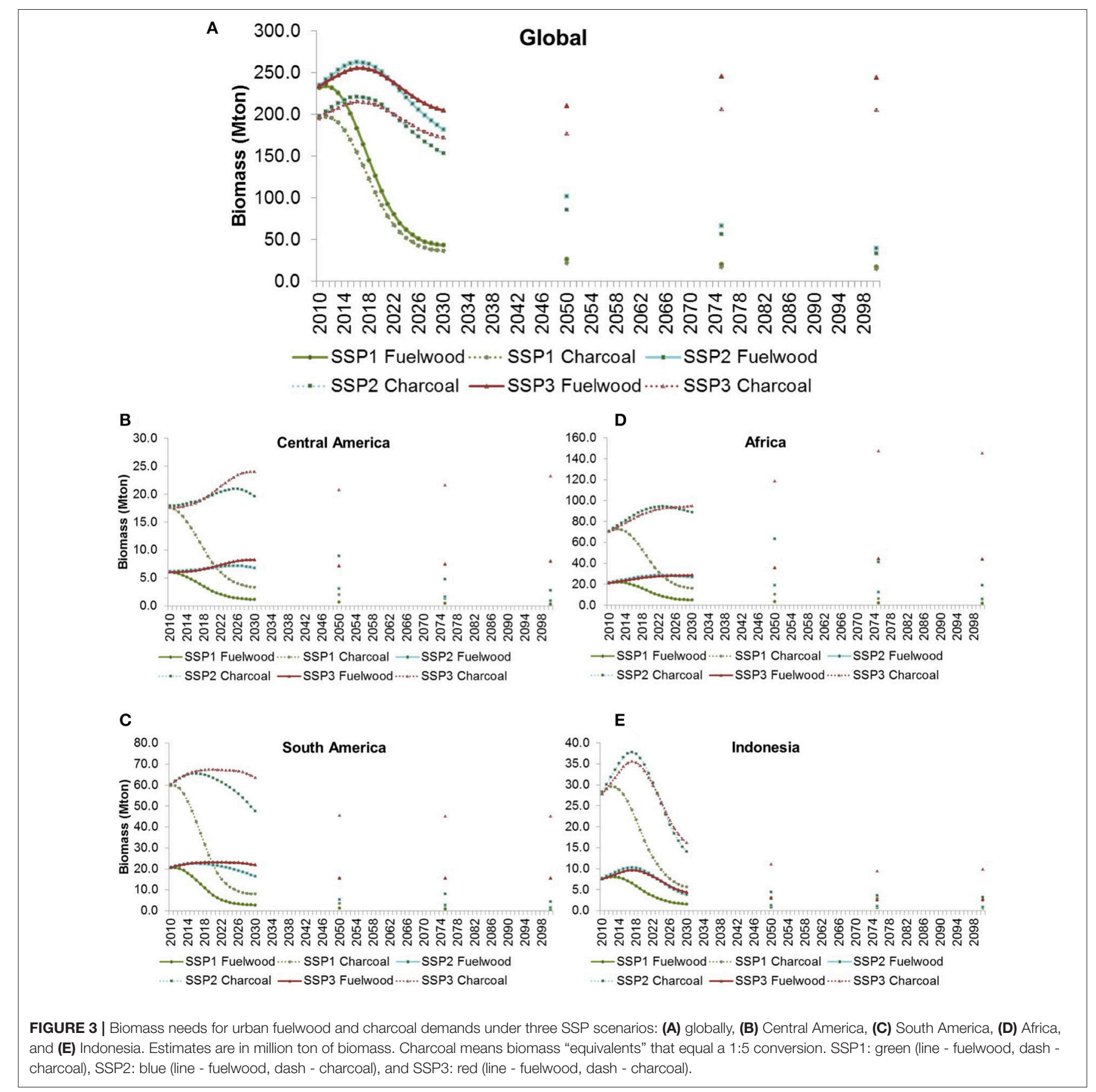

than the demand. However, under SSP3 both Central America and Africa supply and demand become closer at the end of the century (not the log scale on the graph).

\section{DISCUSSION}

We set to assess whether there is enough forest to sustain charcoal production at local and global scales, using a combination of modeling and observation data. The projected population growth and increasing number of urban dwellers will increase the demand for charcoal, but given that this demand is a small fraction of the total traditional fuels, current global biomass and NPP will be able to meet this demand even under the least sustainable scenarios both globally and for each of the focal regions. Our results, assuming only urban uses for charcoal show that under more sustainable scenarios (SSP1 and SSP2) the demand for charcoal will peak around 2020, and then decrease as other energy sources become available. In the four regions we studied, up to $3 \%$ of forested area is needed per year to account for the charcoal demand. In an unsustainable forest 
TABLE 1 | Demand and supply of biomass for charcoal in 2015 (mi ton C).

\begin{tabular}{|c|c|c|c|c|}
\hline $\mathrm{SSP}_{2015}$ & SSP2 2015 & SSP3 $_{2015}$ & $\begin{array}{c}\text { Forest } \\
\text { aboveground } \\
\text { biomass }_{2015}\end{array}$ & $\begin{array}{c}\text { Forest } \\
\text { aboveground } \\
\text { biomass } 2015 \text { not } \\
\text { in protected areas }\end{array}$ \\
\hline 6.95 & 9.25 & 9.1 & 404.4 & 266.3 \\
\hline 23.85 & 32.75 & 33.1 & $13,652.9$ & $7,567.2$ \\
\hline 33.6 & 41.75 & 40.4 & $6,627.9$ & $5,459.5$ \\
\hline 13.85 & 18.3 & 17.15 & $41,42.9$ & $3,274.7$ \\
\hline 84.55 & 109.95 & 106.9 & $43,855.9$ & $32,596.4$ \\
\hline
\end{tabular}

Demand is for urban areas under three SSP scenarios, and supply in forest aboveground biomass. We chose to display scenario results rather than data because there is no systematic data collected over these regions and globally, and because we can then compare current time with future scenario data.

harvesting regime, this means that all forest are cleared within 30 years. On the contrary at these relative low rates, NPP from 10 to $20 \%$ of each of the analyzed regions is able to produce enough biomass, even when accounting for the projected forest losses. We conclude that a sustainable harvesting of the forest for charcoal production is possible as the forest produces enough biomass to meet the demands, but it is dependent on incentives and governance to implement such sustainable regime. The picture, however, is varied for different tropical regions that represent different uses of charcoal.

In Africa, charcoal is still very important as the main source of energy (Mwampamba et al., 2013), and for this continent our results show the lowest ability to meet urban charcoal demands. This is likely because despite a high NPP, the rates of deforestation in Africa are five times higher than the global average (Bowker et al., 2017), and are mostly due to fuel wood consumption (Bailis et al., 2015; Sulaiman et al., 2017). Further, given the very high need for land for food production (Bowers et al., 2017) and the external land grabbing processes that are currently ongoing in the African continent (Johanson et al., 2016; Zoomers et al., 2017), our results may even be underestimates. We estimate that around $0.7 \%$ forested land is needed for charcoal production per year. Further it is also clear that the share of protected forested area is in Africa the smallest of the four regions. Finally, this is the continent where projected population growth achieves the highest values. Our results suggest that charcoal supply to urban dwellers will be possible during the twenty-first century, and demand and supply gap will become smaller by the end of the century.

In Central America, charcoal use is mainly for cultural reasons despite the dominant availability and use of other fuel sources (Ghilardi et al., 2013). Alongside with Africa, we found that this region will also face a closing gap between supply and demand by the end of the century, under the least sustainable scenario. Very worrying is that around 3\% of forested land is needed for charcoal production per year. Central America is particularly important as charcoal use in this region is by cultural choice as there are other energy carriers in the region that supply for energy needs. Thus reduction of biomass pressure on low NPP forests could be achieved through more efficient charcoal production systems or reduced use.
South America highly productive forests may explain why this region is the one the greatest gap between supply and demand, even in the least sustainable scenario. For current charcoal demand, around $0.4 \%$ of forested unprotected area is needed. However, South America is one of the major exporters of charcoal, and internal consumption is still relatively low in contrast to its neighboring Central America (Hillring, 2006).

In Indonesia, like Central America, charcoal is used along with other fuels in an even smaller fraction. This explains why Indonesia supply is able to meet the local demand of biomass. In contrast with the other regions, all our scenarios project a decrease in demand for Indonesia until the end of the century. This is likely why the gap in supply and demand is not comparable to Central America, as Indonesia forests also have among the lowest NPP in comparison to all other regions. Around $0.5 \%$ of forested not protected area is needed per year. However, Indonesia is also a large exporter of charcoal (Hillring, 2006; http://www.trademap.org), so these numbers are probably higher. As projected land use change for oil palm and rubber plantations are enormous, it is highly questionable if Indonesia can have a sustainable charcoal production.

Our results suggest that the charcoal sector does not face major supply constraints, as both globally and regionally biomass productivity is able to meet the biomass demands even under the least sustainable scenarios. However, there are a few caveats for this relatively simplistic suggestion. First, our analysis focused on the dynamics of supply-demand assuming that all supply comes from the region where it is produced, and we know that there is charcoal trade, and charcoal exports globally are growing (http://www.trademap.org). Recent estimates suggest that $51 \%$ of charcoal production comes from Africa and 35\% from South America, but not all the charcoal stays where it is produced and major exports of charcoal occur in Indonesia, Malaysia and China, while major imports occur in Europe, Korea and Japan (Hillring, 2006). Including the dynamics of trade would improve our analysis as it would allow estimating the demand for internal and external needs, and whether trade could meet demands from scarce regions. It would also be important to assess whether trade could be managed to maximize forest protection, and what are the opportunity costs of such approach. Second, we assume an optimal regional use of forest NPP, which might be an unrealistic assumption but a necessary assumption to assess how NPP could provide biomass in the absence of local knowledge on forest NPP use. To contain this assumption we estimated a lower boundary of NPP values by applying a $1 / 3$ multiplier to total NPP, and an upper boundary estimate obtained from tree PFT. We find this is a first order estimate to look into the local capacity to provide biomass for urban dwellers in the studied regions. Future studies can build upon our results to test for differences in regional uses of NPP, and assess optimal allocation strategies. A sustainable harvesting method means that biomass can only be used as long as it meets the abovegroundNPP. This selective thinning should also be optimally placed in space, meaning that the producing industry should have a full rotating scheme around the whole continent, Thirdly, we assume a conversion rate of 1:5 from wood to charcoal; however, we know this factor varies with charcoal production 
TABLE 2 | Tree and wood NPP, and average NPP over the last century (1900-2006).

\begin{tabular}{|c|c|c|c|c|c|c|c|}
\hline & $\begin{array}{l}\text { NPP }\left(m^{t} \text { ton }\right. \\
\left.\text { C.year }{ }^{-1}\right)\end{array}$ & $\begin{array}{l}\text { NPP in protected } \\
\text { areas (mi ton } \\
\text { C.year-1) }\end{array}$ & $\begin{array}{l}\text { Average NPP } \\
\left(k_{1900-2006}\right. \\
\left(\mathrm{kg} \mathrm{m}^{-2} \cdot \text { year }^{-1}\right)\end{array}$ & $\begin{array}{l}\mathrm{NPP}_{\text {Wood }}(\mathrm{mi} \text { ton } \\
\text { C.year-1) }\end{array}$ & $\begin{array}{c}\mathrm{NPP}_{\text {wood }} \text { in } \\
\text { protected areas } \\
\left.\text { (mi ton C.year }{ }^{-1}\right)\end{array}$ & $\begin{array}{l}\mathrm{NPP}_{\text {tree }}(\mathrm{mi} \text { ton } \\
\text { C.year } \\
-1 \text { ) }\end{array}$ & $\begin{array}{c}\mathrm{NPP}_{\text {tree in }} \\
\text { protected areas (mi } \\
\text { ton C.year }{ }^{-1} \text { ) }\end{array}$ \\
\hline S. America & 15,527 & 406 & 0.73 & 5,176 & 1,218 & $3,182.4$ & 2,954 \\
\hline Africa & 15,451 & 2,257 & 0.45 & 5,150 & 681 & $2,651.1$ & 1,243 \\
\hline Indonesia & 3,639 & 578 & 1.12 & 1,210 & 173 & 828.3 & 441 \\
\hline
\end{tabular}

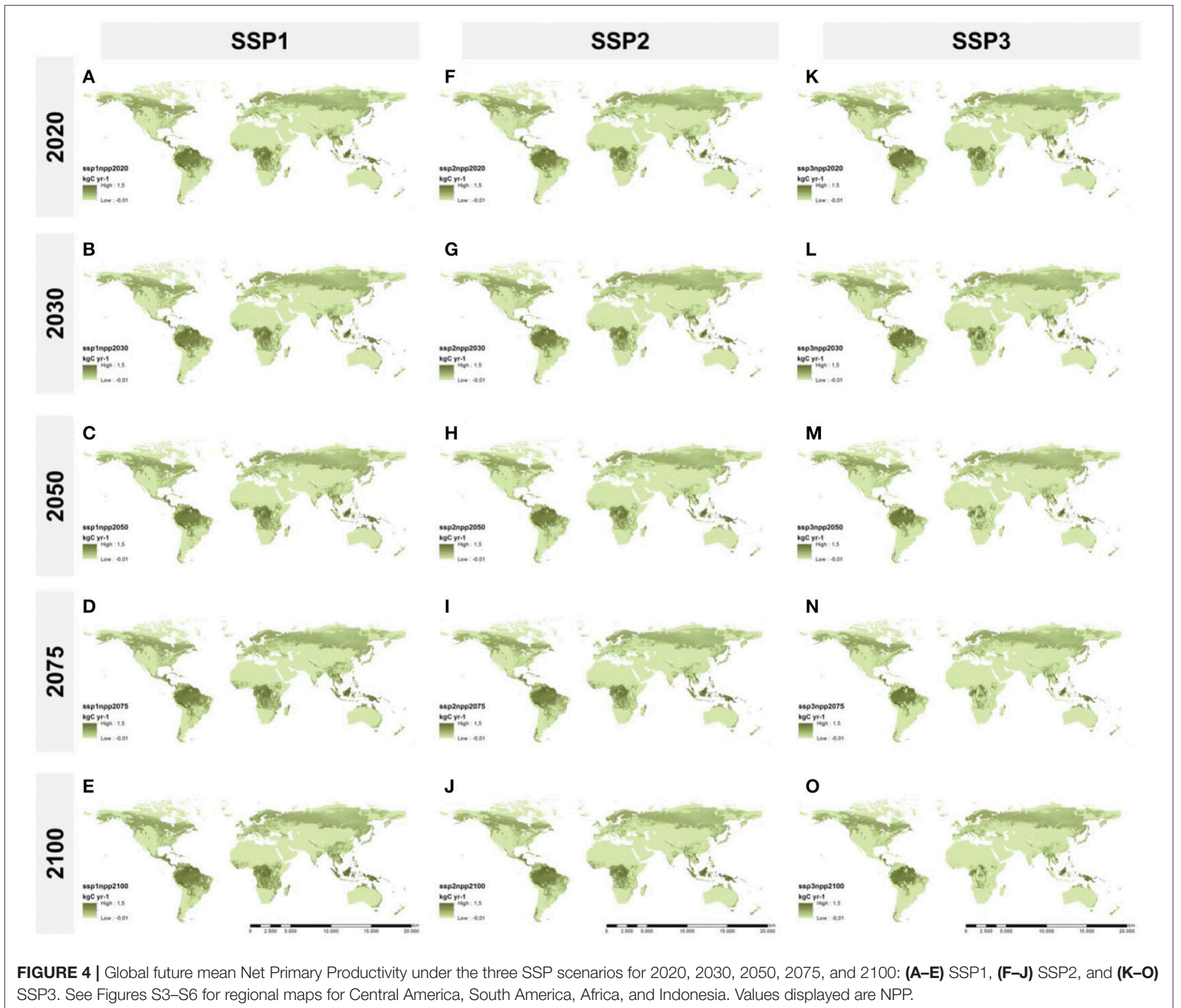

technique. A range of 3 to $12 \mathrm{~kg}$ of biomass is required to produce $1 \mathrm{~kg}$ of charcoal. This suggests that changing production techniques both globally and regionally could be a way forward to make the charcoal sector even more attractive to meet urban residential energy needs. Finally, charcoal is a relatively small fraction of the global and regional energy needs. At least an equal amount of biomass is needed for traditional fuels like fuelwood. Further, other energy carriers may require biomass as primary material or secondary to produce heat to operate the energy production facilities. This means that additional stressors 

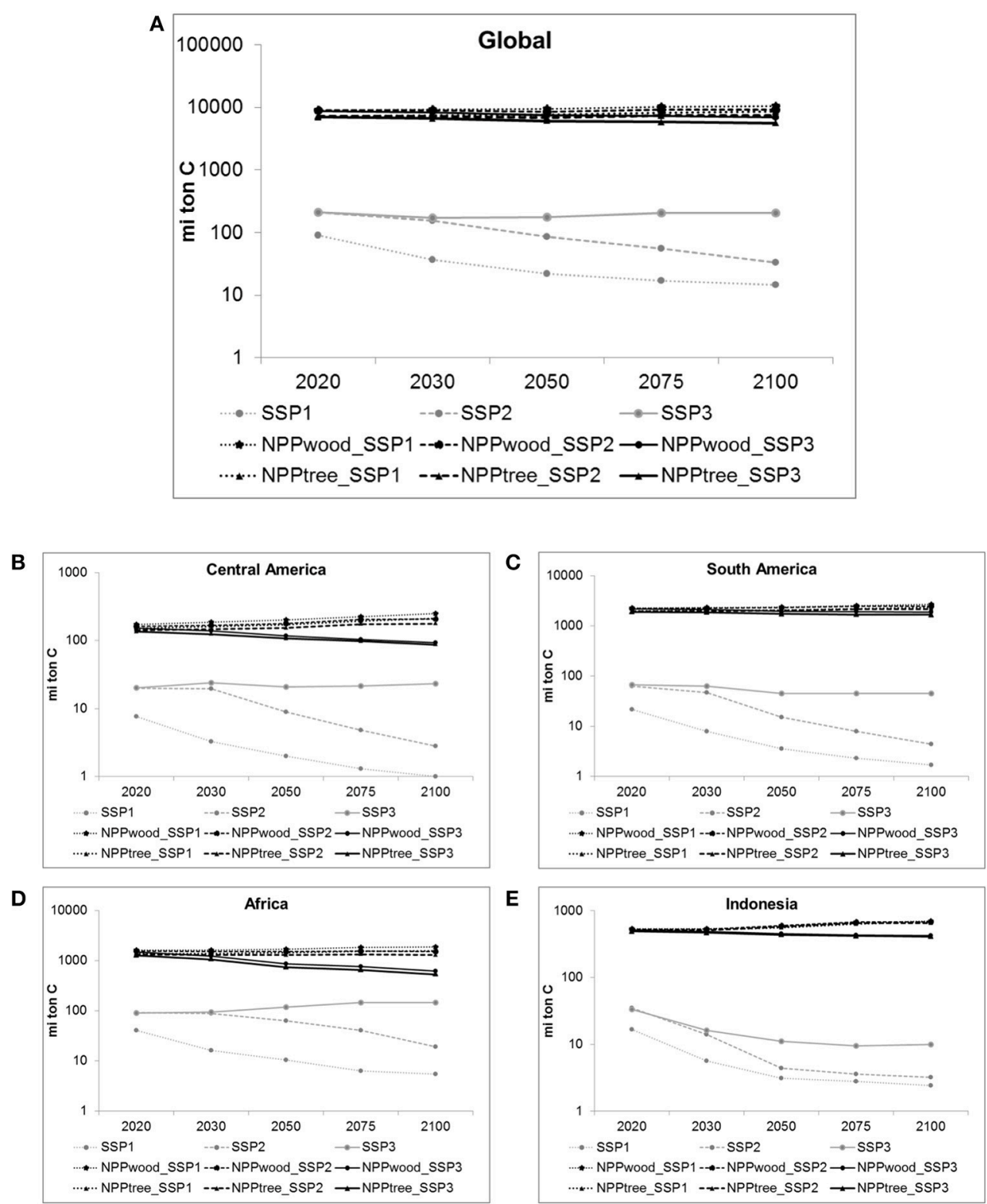

FIGURE 5 | Projected demand and supply of biomass for charcoal (mi ton C) under SSP scenarios for 2020, 2030, 2050, 2075, and 2100. Gray lines are demand and black lines are supply. Full line for SSP3, dashed line for SSP2 and dotted line for SSP1. Globally the supply is always higher than the demand, suggesting that charcoal production is not a large stressor on the system. However, regionally it can be observed that the demand approximates the supply in the case of Central America and Africa under the most unsustainable scenario. (A) Globally, (B) Central America, (C) South America, (D) Africa, and (E) Indonesia.

on local biomass are present and not accounted for in our analysis.

The future of the charcoal sector is not dire. Wood and Baldwin (1985) estimated that for developing countries about $1 \mathrm{~kg}$ of biomass per day gets consumed for every man, woman and child, and this fuel correspond to as much as $95 \%$ of the domestic energy. This biomass can be used for either traditional biofuel or charcoal, and the choice of charcoal over fuelwood is a function of supply, transportation, storage, price and convenience (Zulu and Richardson, 2013). Charcoal represents a small fraction of the energy needs, but its biomass demands are disproportionate and in some regions the gap between supply and demand is closing under the least sustainable scenario. We use a novel combination of empirical data, modeling and scenarios to suggest that charcoal for urban dwellers projected demand is not expected to add significant extra pressures on forests, as long as other energy carriers are made more renewable and sustainable, as our models assume a movement away from charcoal due to gross domestic product growth and improved access to modern 
energy. However, charcoal production can also be made more sustainable. Here we analyzed whether there was sufficient standing biomass and sufficient biomass growth in terms of NPP, but further research is suggested on how meeting charcoal supply might affect other sectors like water, food and biodiversity (Johanson et al., 2016). Our results already suggest a need to cut down massive amounts of forest, under an optimized use of forest NPP. However, it is possible to implement a wood extraction strategy that only requires extracting larger trees, or at larger time intervals (as depicted in Figure 1). Burning of charcoal and associated deforestation amounts to 71.2 mi $\mathrm{tCO}_{2}$ and $1.3 \mathrm{mi} \mathrm{tCH}$ being released to the atmosphere (Chidumayo and Gumbo, 2013). Air pollution by atmospheric particulate matter production from wood is two times larger than that from charcoal, and both are still much higher than electricity $\left(\mathrm{PM}_{10, \text { wood }}=1,200 \mu \mathrm{g} / \mathrm{m}^{3} ; \mathrm{PM}_{10 \text {, charcoal }}=\right.$ $540 \mu \mathrm{g} / \mathrm{m}^{3} ; \mathrm{PM}_{10, \text { electricity }}=200-380 \mu \mathrm{g} / \mathrm{m}^{3}$; Torres-Duque et al., 2008). Wood combustion also releases twice as many polycyclic aromatic hydrocarbons as charcoal, highly toxic environmental compounds and carcinogenic molecules (Oanh et al., 1999). However, with cleaner production systems and changing production methods, higher efficiency might be achievable with reduced emissions and improved air quality. Deforestation rates are responsible for major biodiversity losses (Ahrends et al., 2012). It would be important, however, to determine which woody species are most suited for charcoal production, and

\section{REFERENCES}

Ahrends, A., Burgess, N. D., Milledge, S. A. H., Bulling, M. T., Fisher, B., Smart, J. C. R., et al. (2012). Predictable waves of sequential forest degradation and biodiversity loss spreading from an African city. Proc. Nat. Acad. Sci. U.S.A. 107, 14556-14561. doi: 10.1073/pnas.0914471107

Antal, M. J., and Gronli, M. (2003). The art, science, and technology f charcoal production. Ind. Eng. Chem. Res. 42, 1619-1640. doi: 10.1021/ie0207919

Arnold, J. E. M., Kohlin, G., and Persson, R. (2006). Woodfuels, livelihoods, and policy interventions: changing perspectives. World Dev. 34, 596-611. doi: 10.1016/j.worlddev.2005.08.008

Avitabile, V., Herold, M., Heuvelink, G., Lewis, S. L., Phillips, O. L., Asner, G. P., et al. (2016). An integrated pan-tropical biomass maps using multiple reference datasets. Glob. Change Biol. 22, 1406-1420. doi: 10.1111/gcb.13139

Baccini, A., Goetz, S. J., Walker, W. S., Laporte, N. T., Sun, M., SullaMenashe, D., et al. (2012). Estimated carbon dioxide emissions from tropical deforestation improved by carbon-density maps. Nat. Clim. Change 2, 182-185. doi: $10.1038 /$ nclimate1354

Bailis, R., Drigo, R., Ghilardi, A., and Masera, O. (2015). The carbon footprint of traditional woodfuels. Nat. Clim. Change 5, 266-272. doi: $10.1038 /$ nclimate 2491

Bartholomé, E., and Belward, A. S. (2005). GLC2000: a new approach to global land cover mapping from Earth observation data. Int. J. Rem. Sens. 26, 1959-1977. doi: 10.1080/01431160412331291297

Bond, T. C., Streets, D. G., Yarber, K. F., Nelson, S. M., Woo, J. H., and Klimont, Z. (2004). A technology-based global inventory of black and organic carbon emissions from combustion. J. Geophys. Res. 109, 1-34. doi: $10.1029 / 2003$ jd003697

Bowers, S., Ryan, C., and Jones, X. H. (2017). Understanding Agricultural Drivers of Deforestation Through Remote Sensing. IIED Working Paper. IIED, London.

Bowker, J. N., de Vos, A., Ament, J. M., and Cumming, G. S. (2017). Effectiveness of Africa's tropical protected areas for maintaining forest cover. Conserv. Biol. 31, 559-569. doi: $10.1111 /$ cobi.12851 target extraction toward those or complement biomass needs with directed intensive plantations. The identified research needs can provide important information to better integrate between global models and local conditions to fully understand whether local sustainable optimal pathways in the charcoal nexus can be achieved.

\section{AUTHOR CONTRIBUTIONS}

MS: designed the experiment, collected the data, wrote the manuscript. SD: designed the experiment, wrote the manuscript. VD and MB: collected the data, edited the manuscript. Dv: edited the manuscript

\section{FUNDING}

Funding provided for this research was provided by the Copernicus Institute of Sustainable Development at Utrecht University and by PBL Netherlands Environmental Assessment Agency.

\section{SUPPLEMENTARY MATERIAL}

The Supplementary Material for this article can be found online at: http://journal.frontiersin.org/article/10.3389/fenvs. 2017.00028/full\#supplementary-material

Chidumayo, E. N., and Gumbo, D. J. (2013). The environmental impacts of charcoal production in tropical ecosystems of the world: a synthesis. Energy Sustain. Dev. 17, 86-94. doi: 10.1016/j.esd.2012.07.004

Daioglou, V., van Ruijven, B. J., and van Vuuren, D. (2012). Model projections for household energy use in developing countries. Energy 37, 601-615. doi: 10.1016/j.energy.2011.10.044

FAO (2016). Available online at: http://faostat.fao.org/Portals/_faostat/documents/ pdf/wood\%20charcoal.pdf

Fernandes, S. D., Trautmann, N. M., Streets, D. G., Roden, C. A., and Bond, T. C. (2007). Global biofuel use, 1850-2000. Global Biogeoch. Cycles 21, 1-15. doi: 10.1029/2006GB002836

Fisher, B., Lewis, S. L., Burgess, N. D., Malimbwi, R. E., Munishi, P. K., Swetnam, R. D., et al. (2011). Implementation and opportunity costs of reducing deforestation and forest degradation in Tanzania. Nat. Clim. Change 1, 161-164. doi: 10.1038/nclimate1119

Ghilardi, A., Mwampamba, T., and Dutt, G. (2013). What role will charcoal play in the coming decades? Insights from up-to-date findings and reviews. Energy Sustain. Dev. 17, 73-74. doi: 10.1016/j.esd.2013.02.007

Glaser, B., Lehmann, J., and Zech, W. (2002). Ameliorating physical and chemical properties of highly weathered soils in the tropics with charcoal - a review. Biol. Fert. Soils 35, 219-230. doi: 10.1007/s00374-0020466-4

Gómez-Luna, B. E., Rivera-Mosqueda, M. C., Dendooven, L., Vázquez-Marrufo, G., and Olalde-Portugal, V. (2009). Charcoal production at kiln sites affects $\mathrm{C}$ and $\mathrm{N}$ dynamics and associated soil microorganisms in Quercus spp. temperate forests of central Mexico. Appl. Soil Ecol. 41, 50-58. doi: 10.1016/j.apsoil.2008.08.007

Grubler, A., Bai, X., Buettner, T., Dhakal, S., Fisk, D. J., Ichinose, T., et al. (2012). "Urban energy systems," in Global Energy Assessment - Toward a Sustainable Future, eds T. B. Johansson, N. Nakicenovic, A. Patwardhan, and L. Gomez-Echeverri (Cambridge, UK; New York, NY: Cambridge University Press; Laxenburg: The International Institute for Applied Systems Analysis), 1307-1400. 
Hillring, B. (2006). World trade in forest products and wood fuel. Biomass Bioenergy 30, 815-825. doi: 10.1016/j.biombioe.2006.04.002

Johanson, E. L., Fader, M., Seaquist, J. W., and Nicholas, K. A. (2016). Green and blue water demand from large-scale land acquisitions in Africa. Proc. Natl. Acad. Sci. U.S.A. 113, 11471-11476. doi: 10.1073/pnas.1524741113

Kriegler, E., O’Neill, B. C., Hallegatte, S., Kram, T., Lempert, R. J., Moss, R. H., et al. (2012). The need for and use of socio-economic scenarios for climate change analysis: a new approach based in shared socio-economic pathways. Global Environ. Change 22, 807-822. doi: 10.1016/j.gloenvcha.2012.05.005

Malhi, Y., Doughty, C., and Galbraith, D. (2011). The allocation of ecosystem net primary productivity in tropical forests. Philos. Trans. R. Soc. Lond. B. Biol. Sci. 366, 3225-3245. doi: 10.1098/rstb.2011.0062

Mitchell, T. D., and Jones, P. D. (2005). An improved method of constructing a database of monthly climate observations and associated high-resolution grids. Int. J. Clim. 25, 693-712. doi: 10.1002/joc.1181

Mwampamba, T. H., Ghilardi, A., Sander, K., and Chaix, K. J. (2013). Dispelling misconceptions to improve attitudes and policy outlook on charcoal in developing countries. Energy Sustain. Dev. 17, 75-85. doi: 10.1016/j.esd.2013.01.001

Neufeldt, H., Langford, K., Fuller, J., Iiyama, M., and Dobie, P. (2015). From Transition Fuel to Viable Energy Source: Improving Sustainability in the Subsaharan Charcoal Sector. ICRAF Working Paper No. 196. Nairobi, World Agroforestry Centre.

Oanh, N. T. K., Reutergardh, L. B., and Dung, N.,T. (1999). Emission of polycyclic aromatic hydrocarbons and particulate matter from domestic combustion of selected fuels. Environ. Sci. Technol. 33, 2703-2709. doi: 10.1021/es980853f

Peters, G. P., Andrew, R. M., Boden, T., Canadell, J. G., Ciais, P., Le Quere, C., et al. (2013). The challenge to keep global warming below $2^{\circ} \mathrm{C}$. Nature Clim. Change 3, 4-6. doi: 10.1038/nclimate1783

Piketty, T. (2015). Carbon and Inequality: from Kyoto to Paris. Trends in the Global Inequality of Carbon Emissions (1998-2013) and Prospects for An Equitable Adaptation Fund. Paris: Paris School of Economics.

Poumanyvong, P., and Kaneko, S. (2010). Does urbanization lead to less energy use and lower CO2 emissions? A cross-country analysis. Ecol. Econ. 70, 434-444. doi: 10.1016/j.ecolecon.2010.09.029

Riahi, K., van Vuuren, D. P., Kriegler, E., Edmonds, J., O’Neill, B. C., Fujimori, S., et al. (2017). The shared socioeconomic pathways and their energy, land use, and greenhouse gas emissions implications: an overview. Global Environ. Change 42, 153-168. doi: 10.1016/j.gloenvcha.2016.05.009

Saatchi, S. S., Harris, N. L., Brown, S., Lefsky, M., Mitchard, E. T. A., Salas, W., et al. (2011). Benchmark map of forest carbon stocks in tropical regions across three continents. Proc. Natl. Acad. Sci. U.S.A. 108, 9899-9904. doi: 10.1073/pnas.1019576108

Santoro, M., Beaudoin, A., Beer, C., Cartus, O., Fransson, J. E. S., Hall, R. J., et al. (2015). Forest growing stock volume of the northern hemisphere: spatially explicit estimates for 2010 derived from Envisat ASAR. Rem. Sens. Environ. 168, 316-334. doi: 10.1016/j.rse.2015.07.005

Smith, B., Prentice, I. C., and Sykes, M. T. (2001). Representation of vegetation dynamics in the modelling of terrestrial ecosystems: comparing two contrasting approaches within European climate space. Glob. Ecol. Biogeogr. 10, 621-637. doi: 10.1046/j.1466-822X.2001.00256.x

Stehfest, E., van Vuuren, D., Bouwman, L., and Kram, T. (2014). Integrated Assessment of Global environmental Change with IMAGE 3.0: Model Description and Policy Implications. Den Hague: Netherlands Environmental Assessment Agency (PBL).

Sulaiman, C., Abdul-Rahim, A. S., Mohd-Shahwahid, H. O., and Chin, L. (2017). Wood fuel consumption, institutional quality, and forest degradation in subSaharan Africa: evidence from a dynamic panel framework. Ecol. Ind. 74 414-419. doi: 10.1016/j.ecolind.2016.11.045

Torres-Duque, C., Maldonado, D., Perez-Padilla, R., Ezzati, M., and Viegi, G. (2008). Biomass fuels and respiratory diseases: a review of the evidence. Proc. Am. Thorac. Soc. 5, 577-590. doi: 10.1513/pats.200707100rp

van Vuuren, D. P., Stehfest, E., Gernaat, D. E. H. J., Doelman, J. C., van den Berg, M., Harmsen, M., et al. (2017). Energy, land-use and greenhouse gas emissions trajectories under a green growth paradigm. Global Environ. Change 42, 237-250. doi: 10.1016/j.gloenvcha.2016.05.008

Wood, T. S., and Baldwin, S. (1985). Fuelwood and charcoal use in developing countries. Ann. Rev. Energy 10, 407-429. doi: 10.1146/annurev.eg.10.110185.002203

Zoomers, A., van Noorloos, F., Otsuki, K., Steel, G., and van Westen,. G. (2017). The rush for land in an urbanizing world; from land grabbing towards developing safe, resilient, and sustainable cities and landscapes. World Dev. 92, 242-252. doi: 10.1016/j.worlddev.2016. 11.016

Zulu, L. C., and Richardson, R. B. (2013). Charcoal, livelihoods, and poverty reduction: evidence from sub-Saharan Africa. Energy Sustain. Dev. 17, 127-137. doi: 10.1016/j.esd.2012.07.007

Conflict of Interest Statement: The authors declare that the research was conducted in the absence of any commercial or financial relationships that could be construed as a potential conflict of interest.

Copyright (c) 2017 Santos, Dekker, Daioglou, Braakhekke and van Vuuren. This is an open-access article distributed under the terms of the Creative Commons Attribution License (CC BY). The use, distribution or reproduction in other forums is permitted, provided the original author(s) or licensor are credited and that the original publication in this journal is cited, in accordance with accepted academic practice. No use, distribution or reproduction is permitted which does not comply with these terms. 